\title{
KONSEP 'AQL DALAM AL-QUR'AN DAN NEUROSAINS
}

\author{
Asti Faticha Nurjanah ${ }^{1)}$, Hernantito Sulkhan Hakim ${ }^{2}$, \\ Muhammad Taufiqurrohman Aljalii ${ }^{3)}$, Nungki Nariska ${ }^{4)}$ \\ ${ }^{1}$ Fakultas Agama Islam, Universitas Ahmad Dahlan Yogyakarta \\ faticha20@gmail.com \\ ${ }^{2}$ Fakultas Agama Islam, Universitas Ahmad Dahlan Yogyakarta \\ Hernantito7@gmail.com \\ ${ }^{3}$ Fakultas Agama Islam, Universitas Ahmad Dahlan Yogyakarta \\ Taufiqurrohman@gmail.com \\ ${ }^{4}$ Fakultas Agama Islam, Universitas Ahmad Dahlan Yogyakarta \\ Nariskanungki21@gmail.com
}

\begin{abstract}
In the Qur'an the term brain is not known, to illustrate the intelligence used the term of reason. The brain is the meaning of reason in the physical dimension. 'Aql is the power of thought, effort, deception, trickery, ingenuity, cunning, and the ability to see. Muslim philosophers understand 'Aql as binding, attaching, and limiting. The term 'Aql can be found in Qs. As-Syams: 7-8. Intellect is an active and conscious organ, binding and holding objects of science with words or other forms of symbolism. Neuroscience is neural science that studies the nervous system, mainly studies neurons or nerve cells with a multidisciplinary approach. Neurosains is a science that specializes in scientific studies of the nervous system. Neuroscience has traces in Islam. Islamic education has traces in the nature of neuroscience. Therefore, Islamic education can be integrated-interconnected with neuroscience.
\end{abstract}

\section{Abstrak}

Dalam Alquran istilah otak tidak dikenal, untuk menggambarkan kecerdasan menggunakan istilah akal. Otak adalah arti dari alasan dalam dimensi fisik. 'Aql adalah kekuatan pikiran, usaha, penipuan, tipu daya, kecerdikan, kelicikan, dan kemampuan untuk melihat. Para filsuf Muslim memahami 'Aql sebagai mengikat, melekat, dan membatasi. Istilah 'Aql 
dapat ditemukan di Qs. As-Syams: 7-8. Akal A. adalah organ yang aktif dan sadar, mengikat dan memegang objek ilmu dengan kata-kata atau bentuk simbolisme lainnya. Neuroscience adalah ilmu saraf yang mempelajari sistem saraf, terutama mempelajari neuron atau sel saraf dengan pendekatan multidisiplin. Neurosains adalah ilmu yang mengkhususkan diri dalam studi ilmiah tentang sistem saraf. Neuroscience memiliki jejak dalam Islam. Pendidikan Islam memiliki jejak di alam ilmu syaraf. Oleh karena itu, pendidikan Islam dapat diintegrasikan-interkoneksi dengan neurosains.

Keywords: Brain, 'Aql, Science, Neurosains, Islamic Education

\section{Pendahuluan}

Akal berasal dari bahasa arab yaitu Al-'aql yang artinya adalah mencegah dan menahan, dan bila dihubungkan dengan manusia berarti orang yang mencegah dan menahan hawa nafsunya. ${ }^{1}$

Paradigma lama memandang otak sebagai "seonggok daging lemak" yang terpisah dengan pikiran dan memori. Bahkan, sebagian kalangan mempertentangkan antara otak dan akal. Salah satunya tokoh yang membedakan antara otak dan akal adalah Harun Nasution. Menurutnya, pikiran (akal) bukanlah otak melainkan daya berfikir yang terdapat dalam jiwa manusia. ${ }^{2}$

Secara etimologi, neurosains adalah ilmu neural (neural science) yang mempelajari sistem saraf, terutama mempelajari neuron atau sel saraf dengan pendekatan multidisipliner. ${ }^{3}$ Secara terminologi, neurosains merupakan bidang ilmu yang mengkhususkan pada studi saintifik terhadap sistem saraf. Atas dasar ini, neurosains juga disebut sebagai ilmu yang mempelajari otak dan seluruh fungsi-fungsi saraf belakang. ${ }^{4}$

\footnotetext{
${ }^{1}$ Juwaini dan Nik bin Yusri, "Konsep Akal (suatu analisis terhadap pemikiran alfarabi dan ibnu sina)", Substantia, 12, 2 (2010): 382

2 Taufiq Pasiak, Revolusi IQ/EQ/SQ: Menyingkap Rahasia Kecerdasan Berdasarkan AlQur'an dan Neurosains Mutakbir, dalam Suyadi, Teori Pembelajaran Anak Usia Dini dalam Kajian Neurosains, (Bandung: PT Remaja Rosdakarya, 2017), 59-60.

3 Taufiq Pasiak, Tuhan dalam Otak Manusia, Mewnjudkan Kesehatan Spiritual Berdasarkan Neurosains, dalam Suyadi, Teori Pembelajaran, 7.

${ }^{4}$ Wikipedia, Neurosains, http://id.wikipedia.org/wiki/Neurosains, dalam Suyadi, Teori Pembelajaran, 7.
} 
Tujuan utama dari ilmu ini adalah mempelajari dasar-dasar biologis dari setiap perilaku. Artinya, tugas utama dari neurosains adalah menjelaskan perilaku manusia dari sudut pandang aktivitas yang terjadi didalam otaknya. Penelitian mutakhir di bidang neurosains menemukan sejumlah bukti hubungan tidak terpisahkan antara otak dan perilaku (karakter) manusia. $^{5}$

Menurut Suyadi, hakekat pendidikan islam adalah optimalisasi potensi. Seluruh potensi manusia bertumpu pada otaknya. Ilmu yang mempelajari otak adalah neurosains. Hasil integrasi antara pendidikan Islam dan neurosains dalam penelitian ini disebut Neuroscience Islamic Education. ${ }^{6}$ Neurosains mempunyai jejak di dalam Islam. Pendidikan islam mempunyai jejak di alam neurosains. Oleh karena itu, pendidikan Islam dapat diintegrasi-interkoneksikan dengan neurosains. Melalui metode interpretatif secara intertektualitas dengan penekanan pada meaning of creatifity, integrasi pendidikan Islam dan neurosains dapat dilakukan. $^{7}$

Menurut Anas, mendiskusikan pendidikan tidak pernah selesai, selalu ada sesuatu yang baru di dalam dunia pendidikan. Pendidikan saat ini memiliki tantangan modernitas yang membuat pendidikan harus berinovasi lebih banyak lagi pendidikan Islam. Pendidikan bukan hanya mencari masukan bagus untuk prosesnya menjadi lulusan (output) baik tapi bagaimana proses kualitas itu membuat produk (lulusan) bagus. ${ }^{8}$

Pendidikan dewasa ini bisa menjadi obat mujarab untuk harmonisasi agama dan pengaruh modernisasi. Pendidikan bukan hanya mengedepankan intelektual semata akan tetapi bisa memainkan peran qolb, aqal, nafs dan jism. Dan yang bisa mengembangkan potensi manusia tersebut hanyalah pendidikan Islam.

Dari permasalahan tantangan yang di hadapi madrasah adalah integrasi antara pendidikan Islam dan sains. Khudori Sholeh, menyatakan bahwa sebenarnya lembaga pendidikan Islam (madrasah)

5 Taufiq Pasiak, Pendidikan Karakter Sebagai Pendidikan Otak, dalam Suyadi, Teori Pembelajaran. 8.

6 Suyadi, "Integrasi Pendidikan Islam dan Neurosains dan Implikasinya bagi Pendidikan Dasar (PGMI)", Al-Bidayah 4, no.1 (2012): 111.

${ }^{7}$ Suyadi, "Integrasi Pendidikan", 129.

${ }^{8}$ Muhammad Anas Ma'arif, "Pendidikan Islam dan Tantangan Modernitas (input, proses, dan output pendidikan di madrasah)", Nidhomul Haq, 1, No.2 (2016): 47. 
telah melakukan integrasi tersebut meskipun dalam pengertian sederhana. Lembaga pendidikan Islam mulai dari Madrasah Ibtidaiyah sampai Perguruan Tinggi, memang telah memberikan materi-materi ilmu keagamaan seperti tafsir, hadis, figh, dan seterusnya, dan pada waktu yang sama juga memberikan berbagai disiplin ilmu modern yang diadopsi dari Barat. Artinya, mereka telah melakukan integrasi antara ilmu dan agama.

Dari beberapa masalah tersebut maka pendidikan Islam (madrasah) harus bisa merencanakan, mengatur, mengaplikasikan dan mengembangkan potensi peserta didik baik dari cara penerimaan siswa (in-put), proses pembelajaran dan out-put peserta didik. ${ }^{9}$

Menurut Heru, integrasi ilmu pengetahuan dan agama memiliki nilai penting untuk menghilangkan asumsi antara Agama (Islam) bukan agama kuno yang tidak menerima kemajuan ilmu pengetahuan dan teknologi, tetapi terbuka Agama dan wahyu (al-Qur'an) adalah sumber atau inspirasi semua ilmu. Berbicara tentang integrasi imtaq dan sains dan teknologi sebagai salah satu model dalam pengembangan kurikulum pendidikan Islam. ${ }^{10}$

Dengan integrasi pendidikan agama Islam dengan sains dan teknologi diharapkan pembelajaran yang dilaksanakan menjadi lebih bermakna dan mudah dipahami. Sehingga tujuan pendidikan agama Islam dalam mengarahkan peserta didik untuk mengenal, memahami, menghayati, hingga mengimani, bertaqwa, dan berakhlak mulia dalam mengamalkan ajaran agama Islam dari sumber utamanya yaitu kitab suci Al-Quran dan Al-Hadits, melalui kegiatan bimbingan pengajaran, latihan, serta penggunaan pengalaman dapat terlaksana. ${ }^{11}$

Dari sisi positif, perkembangan iptek telah memunculkan kesadaran yang kuat pada sebagian pelajar akan pentingnya memiliki keahlian dan keterampilan. Utamanya untuk menyongsong kehidupan masa depan yang lebih baik, dalam rangka mengisi era milenium ketiga yang disebut sebagai era informasi dan era bioteknologi. Hal ini sekurang-kurangnya telah memunculkan sikap optimis, generasi pelajar

${ }^{9}$ Ma'arif, "Pendidikan Islam", 48.

${ }^{10}$ Heru Setiawan, "Integrasi Imtaq dan Iptek dalam Pengembangan Pendidikan Islam", Nidhomul Haq, 1, No.2 (2016): 58.

${ }^{11}$ Setiawan, "Integrasi Imtaq dan Iptek", 68. 
umumya telah memiliki kesiapan dalam menghadapi perubahan tersebut. $^{12}$

Tetapi, suksesnya perkembangan dan kemajuan iptek tidak selalu identik dengan keselamatan atau kesejahteraan serta kebahagiaan. Tidak sedikit kehancuran yang ditimbulkan akibat kemajuan iptek tersebut. Misalnya, pencemaran lingkungan dan dekadensi moral, antara lain ditunjukkan oleh maraknya pelacuran, korupsi, kriminalitas dan lain sebagainya. ${ }^{13}$

Di samping itu, penyimpangan atau penyalahgunaan iptek ini telah berkembang dari kemampuan merekayasa benda mati, meningkat ke bio-teknologi untuk merekayasa tumbuh-tumbuhan dan binatang. Kemudian kemampuan ini membuka peluang untuk merekayasa manusia itu sendiri. Dewasa ini telah ditemukan hemoglobin baru untuk mengubah hemoglobin mereka yang rusak atau kurang. Hemoglobin baru ini cocok untuk semua manusia, tetapi ia dibuat dan diolah dari darah babi. Demikian pula dengan maraknya tentang isu ditemukannya cloning manusia.

Kemampuan iptek untuk merekayasa kehidupan tidak hanya terbatas pada merekayasa kehidupan yang sifatnya fisik dengan bioteknologinya, tetapi juga hal-hal yang sifatnya non-fisik dalam tata kehidupan.

Bahkan mampu merekayasa masalah-masalah keagamaan. ${ }^{14}$

\section{B. Pembahasan}

\section{Neurosains dalam Islam}

\section{Konsep 'Aq1 dalam Al-Qur'an}

Menurut Daming, kecerdasan adalah salah satu kapasitas di antara kapasitas manusia di mana tujuannya sebagai alat dan sepasang skala pengetahuan untuk memahami hal yang benar dan salah. Cerdas dalam Al-Qur'an dapat dimaksudkan sebagai media untuk memikirkan otorisasi dan ciptaan Allah SWT dalam segala keadaan. Kecerdasan bisa menunjukkan kasih sayang. Orang pintar akan belajar dari firman Allah

\footnotetext{
12 Setiawan, "Integrasi Imtaq dan Iptek", 63.

${ }^{13}$ Setiawan, "Integrasi Imtaq dan Iptek", 61.

${ }^{14}$ Setiawan, "Integrasi Imtaq dan Iptek", 61.
} 
SW'T sebagai petunjuk menuju ke arah yang benar. Jika kecerdasan digunakan dengan baik, maka moral manusia akan menjadi sempurna. ${ }^{15}$

Akal adalah karunia yang paling besar, oleh sebab itu harus dijaga. Akal diberikan oleh Allah kepada manusia sebagai makhluk yang tertinggi kedudukannya dimata Allah. Dengan akal manusia mampu menjaga adabnya kepada Allah, dan juga mampu menjaga adabnya kepada alam dunia. Orang cerdas adalah orang yang pandai menghitung secara cermat, bekerja didunia untuk kepentingan akhirat. ${ }^{16}$

Menurut Hodri, tidak dapat dipungkiri bahwa Al Qur'an akan selalu menjadi referensi (marja') bagi umat Islam dalam setiap pemikiran dan tindakan, diikuti kemudian oleh al-Sunnah di posisi kedua, baik sebagai referensi dalam memahami Alquran atau sebagai sumber independen dalam memahami dan menyelesaikan kasus-kasus tertentu. Fakta ini telah mendorong lahirnya berbagai pola penafsiran atau komentar para ulama Al-Quran yang terus mengalami pertumbuhan metodis yang dinamis.

Akal (al-'Aql) adalah salah satu topik perdebatan di kalangan umat Islam, terutama di kalangan teolog atau mutakallimîn terhadap filsuf, yang belum memperoleh persimpangan yang memuaskan. ${ }^{17}$ Makna 'aql dalam al-Qur'an adalah simbiosa potensi intuitif (kecerdsasan emosional) dan potensi diskursif (kecersasan intelektual) dalam usaha mengetahui, memikirkan, merenungkan, menyelami, memahami, dan merasakan berbagai fenomena fisik maupun informasi metafisik. Dengan menggabungkan dua kecerdasan tersebut, manusia diharapkan bisa sampai pada Hakikat Terakhir, Kebenaran Tertinggi, Asal dari semua yang ada. ${ }^{18}$

Menurut bahasa kata akal berasal dari bahasa arab yaitu Al-'aql yang artinya adalah mencegah dan menahan, dan bila dihubungkan dengan manusia berarti orang yang mencegah dan menahan hawa nafsunya ${ }^{19}$. Al-quran menggunakan kata al-'aql dalam bentuk kata kerja, ini

15 Muh Daming K., "Akal Perspektif Al-Qur'an", Zawiyah Jurnal Pemikiran Islam, 2, No.1 (2016): 19.

${ }^{16}$ Daming, "Akal Perspektif Al-Qur'an", 33.

17 Hodri, "Penafsiran Akal dalam Al-Qur'an", Mutawatir: Jurnal Keilmuan Tafsir Hadis, 3, No.1 (2013): 1.

${ }^{18}$ Hodri, "Penafsiran Akal", 22.

${ }^{19}$ Juwaini dan Yusri, "Konsep Akal", 382. 
maknanya adalah akal merupakan suatu proses, bukan subyek yang bekerja, berfikir dan memahami, akan tetapi Al-'aql adalah nama suatu pekerjaan yang dilakukan oleh $\mathrm{Al}$-qolbu. Karena banyak ayat Al-quran juga yang menyebutkan memahami sesuatu bukan hanya dengan akal tetapi juga dengan qolbu. ${ }^{20}$

Dalam al-Qur'an dimintakan pada manusia untuk berpikir dan alQur'an juga memperhatikan mengagungkan kebesaran akal dan kedudukannya pada manusia. "Sesungguhnya binatang (makhluk) yang seburuk-buruknya pada sisi Allah yaitu manusia yang bisu, tuli, yang tidak cakap atau tidak pandai mempergunakan akal" (QS. al-Anfal : 22). Dan barang siapa yang kami panjangkan umurnya niscaya kami kembalikan dia kepada kejadiannya, maka apakah mereka tidak memikirkan" (QS. Yasin: 68). Pernyataan-pernyataan ayat al-Qur'an di tersebut menunjukkan bahwa Allah menyuruh kita menggunakan akal sebagai alat berpikir untuk merefleksikan realitas agar dapat melahirkan pengetahuan. Bahkan wajib bagi manusia menggunakan akal dan memberikan kedudukan yang tinggi terhadap akal. Namun demikian ketika manusia menggunakan akal dalam implikasinya. Akal memiliki keterbatasan dan kelemahan. ${ }^{21}$

\section{Kajian Otak dalam Neurosains}

Secara anatomis, bongkahan otak dapat dibagi menjadi otak besar (cerebrum), otak kecil (berebellum), batang otak (brain stem), dan sistem limbik. Otak besar berhubungan dengan pembelajaran, otak kecil bertanggung jawab dalam proses koordinasi dan keseimbangan, batang otak mengatur denyut jantung serta proses pernapasan yang sangat penting bagi kehidupan, dan simtem limbik lebih kepada pengaturan emosi dan memproses memori emosional. ${ }^{22}$

Secara fisik otak (neuroanatomi) terbelah menjadi dua, kiri dan kanan, tetapi perbedaan kedua belahan fisik tersebut tidak sebesar perbedaan fungsinya (neurofisiologi).Kontrol terhadap gerakan dan sensasi tubuh terbagi rata diantara dua belahan otak, hanya saja dengan

${ }^{20}$ Juwaini dan Yusri, "Konsep Akal", 384.

${ }^{21}$ Lukman Hakim Fuadi, "Peran Akal Menurut Pandangan Al-Ghazali", Jurnal Substantia, 15, No.1 (2013): 86.

${ }^{22}$ Suyadi, Teori Pembelajaran, 83-84 
cara bersilangan. Artinya, otak kiri mengontrol tubuh bagian kiri. Atas dasar inilah banyak orang beranggapan bahwa kedua belahan otak mempunyai fungsi khusus (spesialisasi) secara berbeda. Namum, anggapan ini dipatahkan oleh fakta saintifik mutakhir bahwa orang kidal memahami melodi (yang seharusnya diproses otak kanan) justru diproses secara baik melalui organ tubuh, khususnya telinga bagian kanan. Artinya, orang kidal memproses musik menggunakan otak kiri mereka. Dalam penelitian lebih lanjut, ternyata orang yang tidak kidal, atau orang normal pada umumnya juga menggunakan telinga kiri untuk memproses musik. ${ }^{23}$ Hal ini mematahakan argument mengenai spesialisasi fungsi otak kiri dan otak kanan. ${ }^{24}$

\section{3. 'Aq1 dan Otak dalam Al-Qur'an dan Neurosains}

Menurut Fuadi, intelek adalah alat pemikiran yang terkandung dalam manusia, pikiran manusia berbeda dari makhluk lain karena akal hanya diberikan pada manusia dan tidak diberikan kepada makhluk lain. Perbedaan ini telah membuat manusia lebih unggul dan lebih pintar dalam mengatur hidup mereka. Karena itu manusia dengan kecerdasan yang jelas akan menemukan Tuhan sebagai hasil akhir dari kehidupan nyata. ${ }^{25}$

Salah satu unsur terpenting bagi manusia adalah akal. Akal merupakan alat untuk berpikir dan dia tidak bisa direalisasikan dalam bentuk konkritnya, akan tetapi secara abstrak akal berupa ideal yang utama dari diri manusia. Adanya akal telah mengangkat manusia lebih jauh sempurna dibandingkan dengan makhluk lain. Akal sering diidentikkan dengan otak yang selalu siap menerima segala rangsangan dari indra melalui rangsangan itulah kemudian lahir berbagai rasa dan karsa. Rekayasa tersebut terlihat adanya unsur kebenaran bila ditinjau dari segi peranannya, namun pada hakikatnya memiliki perbedaan yang jauh. Otak mempunyai kelemahan dan keterbatasan, sedangkan hakikat otak itu sendiri merupakan sarana untuk memahami dan menanggapi pengalaman, sementara akal sendiri bekerja lebih jauh lagi sesuai dengan

${ }^{23}$ Donald Olding Hebb, Teori neurofisiologis dominan, dalam B.R. Hergenhahn dan Mathew H. Olson, Theories of Learning, dalam Suyadi, Teori Pembelajaran, 66-67.

${ }^{24}$ Suyadi, Teori Pembelajaran, 67.

${ }^{25}$ Fuadi, "Peran Akal", 81. 
potensi dan daya yang ada padanya. Akal mendapat pengetahuanpengetahuan yang tidak terbatas dengan pengalaman indera, ia sanggup memastikan lebih mendalam melalui pendayagunaannya. ${ }^{26}$

Dalam al-Qur'an istilah otak tidak dikenal, untuk menggambarkan kecerdasan digunakan istilah akal. Otak merupakan makna akal dalam dimensi jasmani. Kata akal (dalam makna rasio/daya pikir) dalam alQur;an dinyatakan dengan beberapa istilah, yaitu tafakkur, tadabbur, allub, al-hujjah, al-hijr dan al-nuha. Shihab (2006:vol:15:178) berpendapat bahwa akal adalah kekuatan yang menghalangi pemiliknya melakukan sesuatu yang tidak wajar. Akal memikirkan, memahami, serta menimbang yang lahir dan dan yang batin dari suatu persoalan. Akal mampu membedakan antara yang baik dan buruk, kemampuan untuk melihat jauh kedepan, mengatur dan mengelola, akal adalah pelita yang dengannya ditembus yang tersirat dari yang tersurat, kermampuan menampung pengalaman, menghubugkan masa lalu dengan masa kini serta menarik kesimpulan dan pelajaran dari kedua masa itu. Dalam maknanya yang demikian akal merupakan manifestasi kecerdasan manusia. Akal memiliki kemampuan berfikir dan memahami dari obyek yang nampak maupun yang abstrak seperti kehidupan pasca kematian semisal alam barzah, surga dan neraka. Akal juga mampu mengarahkan tingkah laku individu untuk berprilaku positif atau negatif. ${ }^{27}$

\section{'Aq1 dalam Filsafat Islam}

Menurut Syamsuddin, kedudukan Al-Qur'an adalah sebagai wahyu, sebagaimana epistemologi Islam mengartikulasikannya sebagai sumber inspirasi bagi akal dalam menemukan kebenaran, maka akal memiliki kedudukan penting dalam ruang lingkup agama-Islam, dan kedudukan Al-Qur'an sebagai wahyu tidak dapat dipungkiri. ${ }^{28}$

Arti penting kedudukan akal dalam pemikiran filsafat Islam telah melewati lima tahap perkembangan, yaitu; pertama, tahap diterimanya Al-Quran oleh umat Islam sebagai satu-satunya jalan spiritual dan

\footnotetext{
${ }^{26}$ Fuadi, "Teori Akal", 83-84.

${ }^{27}$ Elfi Rimayati, "Memadukan Otak dan Hati dalam Bimbingan Belajar Islami", Majalab Ilmiah Pawiyatan, 20, No. 2 (2013): 28.

${ }^{28}$ Mukhtasar Syamsuddin, "Hubungan Wahyu dan Akal dalam Tradisi Filsafat Islam", Jurnal Filsafat: 127.
} 
pedoman kehidupan, kedua, tahap yang ditandai dengan bangkitnya pemikiran-pemikiran yurispridensi dan teologi Islam yang secara khusus menunjuk pada munculnya empat mazhab/aliran besar, yaitu Hanafi, Syafi'i, Hanbali, dan Maliki yang kemudian diikuti oleh aliran-aliran kecil seperti Sunni dan Syiah, ketiga, adalah kelanjutan atau bahkan imitasi dari tahap kedua di atas yang memunculkan pemikiran model tradisionalis dan konvensionalis di kalangan kaum Muslim, dan keempat, tahap yang ditandai dengan penolakan atas otoritas doktiner kaum yurisprudensial (fuqaha) dan sufisme, dan kelima, tahap pemikiran kontemporer yang ditandai oleh berkembangnya gerakan revivalisme keagamaan dan meluasnya ketertarikan pada ilmu dan teknologi. ${ }^{29}$

\section{Konsep Akal Bertingkat Ibnu Sina}

Menurut Nik dan Yusri, penghargaan terbesar terhadap kecerdasan manusia adalah diberikan oleh Al-Qur'an, Al-Qur'an benar-benar menghargai kecerdasan manusia, oleh karena itu Kitab Syar'i (Hukum Tuhan) hanya ditujukan kepada orang-orang dengan kapasitas intelek mereka. Selain itu, banyak ayat Al-Qur'an dan hadits telah mendorong orang untuk menggunakan kecerdasan mereka dan menunjukkan posisi nalar dalam hukum Islam. ${ }^{30}$

Islam sangat menghargai akal manusia karena akal adalah daya fikir atau proses pikiran yang lebih tinggi yang berkenaan dengan pengetahuan, daya akal budi, kecerdasan berfikir. Para filosof bersepakat bahwa akal memiliki kedudukan yang lebih tinggi dan bersikukuh menyatakan bahwa berkat akal kecerdasan manusia dapat membuka kunci kebenaran tanpa rujukan langsung kepada Al-Qur'an dan hadits. ${ }^{31}$

Taufik Pasiak menjelaskan "otak" dan al-Aql, al-Qolb, an-Nafs, serta ar-Ruh bisa dilacak dalam filsafat akal bertingkat Ibn Sina. Ibn Sina adalah filsuf muslim terkemuka yang juga berprofesi sebagai dokter. Bahkan, Ibn Sina adalah perintis ilmu kedokteran yang dikembangkan

\footnotetext{
${ }^{29}$ Syamsuddin, "Hubungan Wahyu", 129.

${ }^{30}$ Nik dan Yusri, "Konsep Akal", 381.

${ }^{31}$ Nik dan Yusri, "Konsep Akal", 397.
} 
hingga saat ini. Karyanya yang berjudul Al-Qanun fi Al-Isyarat wa AlTanbihat, Al-Qanun fi Al-Thibb menjadi bukti nyata akan hal ini. ${ }^{32}$

Akal bertingkat Ibn Sina terdiri dari empat elemen, yakni akal aktif, akal actual, akal potensial, dan akal empirik. Dalam hal ini, Taufik Pasiak menginterpretasikan hierarki akal bertingkat Ibn Sina tersebut sebagai otak aktif, otak aktual, otak potensial, dan otak empirik. ${ }^{33}$

Pertama, akal aktif. Akal aktif adalah potensi otak dan segala sesuatau yang dimungkinkan oleh kehadiran pencipta otak. ${ }^{34}$ Akal aktif juga sering disebut otak esensial, seperti: "mengapa atau untuk apa otak diciptakan?" Otak esensial atau akal aktif ini berpikir keras untuk menjawab pertanyaan-pertanyaan esensial dan berujung pada kesimpulan (jawaban) bahwa otak mempunyai kemampuan untuk berhubungan dengan Tuhan. Otak esensial inilah yang sering disebut para filsuf sebagai emanasi (pacaran Tuhan) karena otak ini sering "berprasangka" kepada Tuhan..$^{35}$ Artinya Tuhan masuk didalam pikiran manusia melalui otak esensial atau akal aktif ini. Peristiwa ini sempat menggemparkan ilmuwan, ketika para neurosaintis mempublikasikan hasil temuannya dengan membuat pertanyaan, "Tuhan di dalam otak manusia". Artinya, berpikir tentang Tuhan (termasuk beribadah dan berdoa) mempunyai jejak neurobiologis di dalam otak manusia. ${ }^{36}$

Akal aktual adalah otak yang mengaktualkan potensi unlimited-nya secara tak terindrai. Otak aktual adalah otak yang memegang pusat kendali atas perasaan (emosi), pendengaran, penglihatan, bahasa, dan pelbagai fungsi luhur lainnya. Aktivitas merasa, mendengar, melihat, berpikir, mengingat, dan lain-lain merupakan aktivitas yang tak dapat dilihat secara empiris, tetapi dapat dibuktika secara rasionalis. Misalnya, ketika seseorang menyimpan ingatan tentang peristiwa tertentu, hal itu tidak dapat dilihat melalui alat atau teknologi pencitraan otak secanggih apapun. Namun, ketika orang itu menceritakan kembali atas apa yang diingat dalam otaknya, hal itu menjadi bukti nyata. ${ }^{37}$

\footnotetext{
32 Suyadi, Teori Pembelajaran, 77.

33 Taufiq Pasiak, Antara Tuhan Empirik dan Kesehatan Spiritual, dalam Suyadi, Teori Pembelajaran, 77.

34 Pasiak, Antara Tuhan Empirik, dalam Suyadi, Teori Pembelajaran, 77.

35 Suyadi, Teori Pembelajaran, 77.

36 Suyadi, Teori Pembelajaran, 77.

${ }^{37}$ Pasiak, Antara Tuhan Empirik, dalam Suyadi, Teori Pembelajaran, 77-78.
} 
Akal potensial adalah otak manusia, dalam pengertian tak terindrai. Otak dalam pengertian ini adalah otak sebagai pusat kendali seluruh gerak organ tubuh, termasuk pusat kendali perilaku baik dan buruk. Dengan demikian, otak bukan sekedar seonggok lemak, tetapi lebih sebagai mesin yang hidup (the living machine) yang jika mesin ini berhenti beroperasi, matilah seluruh organ tubuh lainnya (meninggal dunia). Pemahaman yang terbatas terhadap otak dalam pengertian ini sering menjerumuskan pada pemahaman yang salah bahwa "otakpikiran", "jiwa-badan", maupun "jasmani-ruhani" terpisah sama sekali. ${ }^{38}$

Akal empirik adalah otak yang terindrai. Otak inilah yang secara empiris dapat dilihat dan diraba serta gambarnya bertebaran dimanamana. Otak dalam pengertian ini pula adalah otak yang secara selulermolekuler dapat diamati dengan teknologi pencitraan otak. Pada umumnya, hanya "otak empirik" inilah yang dipahami masyarakat secara luas. Mereka tidak tahu-menahu tentang keberadaan otak aktif, otak aktual dan otak potensial atau akal aktif, akal aktual, akal potensial. Akibatnya, mereka menolak jika otak disamakan dengan jiwa, pikiran, hati, termasuk al-Aql, al-Qolb, an-Nafs, dan ar-Ruh. ${ }^{39}$

\section{Aql dan Otak dalam Pendidikan Islam}

Menurut Rusdianto, manusia adalah ciptaan Allah swt. yang tertinggi dan sempurna. Manusia diciptakan sebagai makhluk individu dan sosial. Manusia dalam menjalani kehidupan tidak terlepas dari lingkungan dan tidak dapat hidup menyendiri tanpa bantuan orang lain. Pada hakekatnya pada diri manusia terdapat hasrat yang mendorong untuk hidup bermasyarakat, yakni hasrat mempertahankan diri, berjuang, harga diri, bergaul, kebebasan dan tolong menolong. ${ }^{40}$

Pelaksanaan pendidikan Islam terutama adalah Alquran dan hadis. Alquran diturunkan kepada umat manusia untuk memberi petunjuk kearah jalan hidup yang lurus dalam arti memberi bimbingan dan petunjuk kearah jalan yang di ridhai Allah SWT. ${ }^{41}$

${ }^{38}$ Pasiak, Antara Tuhan Empirik, dalam Suyadi, Teori Pembelajaran, 78.

39 Suyadi, Pembelajaran, 78-79.

40 Rusdianto, "Interaksi Neurosains Holistik dalam Perspektif Pendidikan dan Masyarakat Islam", Hunafa: Jurnal Studia Islamika, 12, No.1 (2015): 72.

${ }^{41}$ Rusdianto, "Interaksi Neurosains", 85. 
Menurut Sri Astuti, kemajuan ilmu pengetahuan dan teknologi yang dicapai oleh manusia modern masíh menyisakan misteri. Misteri yang dimaksud adalah manusia belum mampu memecahkan secara jelas hakikat manusia yang sebenarnya. ${ }^{42}$ Menurut Harun Nasution berpandangan bahwa perbedaan utama konsep tentang manusia menurut pandangan Barat dan Timur (Islam) adalah di Barat manusia dipandang sebagai tubuh dan akal atau otak, sementara di Timur manusia dilihat sebagai tubuh, akal, dan hati nurani (qalb). ${ }^{43}$

Menurut Suyadi, di dalam dunia pendidikan, perdebatan dua kubu (otak-pikiran; jiwa-badan; akal-hati) hingga saat ini belum selesai. Sekadar contoh, peserta didik yang pandai dalam bidang olahraga dan musik biasanya rendah dalam bidang sains dan matematika. Sebaliknya, siswa yang unggul dalam bidang sains dan matematika, pada umumnya tidak pandai dalam hal olahraga dan musik. Bahkan, sistem pendidikan nasional di negeri ini tetap tidak meluluskan siswa yang nilai matematikanya dibawah rata-rata meskipun ia menjadi juara olahraga tingkat nasional. ${ }^{44}$ Contoh lain adalah pendidikan islam melarang peserta didik untuk terlalu mengagung-agungkan akal-pikiran karena dalam agama yang terpenting adalah kemuliaan hati dan akhlak mulia. Pendidikan islam kemudian menyuarakan rohani atau suara hati sebagai entitas yang berhubungan langsung dengan perilaku. Hal ini berbeda dengan contoh kasus sebelumnya yang memandang otaklah yang menentukan perilaku, khususnya perilaku berprestasi. ${ }^{45}$

Menurut Aris, masalah utama yang dihadapi oleh dunia Muslim, khususnya pendidikan Islam saat ini adalah dimulainya sains sekuler. Ilmu disajikan dalam bentuk dikotomi. Untuk memuluskan isu pendidikan Islam, diperlukan rekonstruksi filsafat pendidikan Islam. Tujuan pendidikan berpikir harus diarahkan untuk mempersiapkan seseorang untuk dapat hidup dalam komunitas bersama dengan perilaku keahlian yang dipilih sesuai dengan bakat dan potensi mereka. ${ }^{46} \mathrm{Al}-$

42 Sri Astuti A. Samad, "Konsep Ruh dalam Perspektif Psikologi Pendidikan Barat dan Islam", Fenomena, 7, No.2 (2015): 215.

${ }^{43}$ Samad, "Konsep Ruh", 216.

44 Suyadi, Teori Pembelajaran, 10.

45 Suyadi, Teori Pembelajaran, 10.

46 Aris Try Andreas Putra, "Pemikiran Filosofis Pendidikan Ibnu Sina dan Implikasinya pada Pendidikan Islam Kontemporer", Literasi, 6, No.2 (2015): 191. 
Qur'an dan konsep tauhid sebagai Basis Pendidikan Islam. AlQur'an merupakan kalam tuhan yang kebenarnya bersifat absolut dan tidak diragukan. Al-Qur'an merupakan sumber nilai, norma dan didalamya terdapat ayat-ayat pengetahuan. Pendidikan Islam harus diberikan secara langsung maupun tidak langsung secara dini. Individu harus memiliki pengetahuan keagamaan dan pengembangan kapasitas intelektual. Pendidikan interkoneksi-integrasi. Pendidikan integrasi interkoneksi menginginkan tidak ada pertentangan antara ilmu-ilmu agama dan ilmu umum. ${ }^{47}$

Menurut Wathon, neuroscience adalah sistem pendidikan baru yang mempelajari sistem saraf. Pendidik umumnya jarang memperhatikan masalah ini. Sehingga terjadi perdebatan antara dua sisi otak-pikiran, jiwa-tubuh, pikiran-hati. Dalam ilmu saraf itu sendiri mempelajari neuroanatomi dan neurofisiologi, keduanya perlu dipelajari untuk meningkatkan kualitas pembelajaran yang sangat menyenangkan. ${ }^{48}$

Neurosains memiliki banyak cabang ilmu tentang syaraf. Neuroanatomi (struktur otak) dan neurofisiologi (fungsi otak) perlu dipertimbangkan para pendidik untuk digunakan sebagai dasar keberhasilan mematangkan keberhasilan masa depan anak di mulai dari proses pengolahan otak di masa golden ages. ${ }^{49}$

Menurut Rimayati, hampir di semua lembaga pendidikan di Indonesia, kecerdasan intelektual (Intelectual Quotient/ IQ) masih mendominasi ukuran kecerdasan seseorang bahkan menjadi penentu kelulusan peserta didik. Tuntutan terhadap aspek kecerdasan intelektual ini disinyalir menjadi pemicu rendahnya moralitas peserta didik lantaran kecerdasan-kecerdasan lain seperti kecerdasan emosi (Emotional Quotient/ EQ), kecerdasan spiritual (Spiritual Quostient/ SQ), kecerdasan sosial (Social Quostient/ SsQ), dan kecerdasan personal (Personal Quostient/ PQ) yang bermuara di dalam hati masih terabaikan. ${ }^{50}$

${ }^{47}$ Putra, "Pemikiran Filosofis Pendidikan", 199-200.

48 Aminul Wathon, "Neurosains dalam Pendidikan", Jurnal Lentera: Kajian Keagamaan, Keilmuan, dan Teknologi, 14, No.1 (2016): 284.

${ }^{49}$ Wathon, "Neurosains dalam", 293.

${ }^{50}$ Rimayati, "Memadukan Otak", 24. 
Menurut Muhaimin (2009:35) Intelegence Quostient (IQ) menyengkut cerdas, pintar, kemampuan membedakan yang baik dan buruk, benar dan salah, serta menentukan kemampuan prioritas atau mana yang lebih bermanfaat. Emotional Quostient (EQ) menyangkut kemampuan mengendalikan emosi, mengerti perasaan orang lain, senang bekerja sama, menunda kepuasan sesaat, dan berkepribadian stabil.

Sedangkan Spiritual Quostient menyangkut kemampuan merasa selalu diawasi oleh Allah (iman), gemar berbuat lillahi ta'ala/ikhlas tanpa pamrih, disiplin beribadah mahdah, sabar berikhtiar, pandai bersyukur dan berterima kasih. Kecerdasan spiritual dalam makna yang demikian telah dikonversikan ke dalam nilai-nilai agama Islam. ${ }^{51}$

\section{Kesimpulan}

Kecerdasan adalah salah satu kapasitas di antara kapasitas manusia di mana tujuannya sebagai alat dan sepasang skala pengetahuan untuk memahami hal yang benar dan salah. Cerdas dalam Al-Qur'an dapat dimaksudkan sebagai media untuk memikirkan otorisasi dan ciptaan Allah SWT dalam segala keadaan. Kecerdasan bisa menunjukkan kasih sayang. Orang pintar akan belajar dari firman Allah SWT sebagai petunjuk menuju ke arah yang benar. Jika kecerdasan digunakan dengan baik, maka moral manusia akan menjadi sempurna.

Akal adalah karunia yang paling besar, oleh sebab itu harus dijaga. Akal diberikan oleh Allah kepada manusia sebagai makhluk yang tertinggi kedudukannya dimata Allah. Dengan akal manusia mampu menjaga adabnya kepada Allah, dan juga mampu menjaga adabnya kepada alam dunia.

Orang cerdas adalah orang yang pandai menghitung secara cermat, bekerja didunia untuk kepentingan akhirat. Menurut bahasa kata akal berasal dari bahasa arab yaitu Al-'aql yang artinya adalah mencegah dan menahan, dan bila dihubungkan dengan manusia berarti orang yang mencegah dan menahan hawa nafsunya.

${ }^{51}$ Rimayati, "Memadukan Otak", 29. 
Secara anatomis, bongkahan otak dapat dibagi menjadi otak besar (cerebrum), otak kecil (berebellum), batang otak (brain stem), dan sistem limbik. Otak besar berhubungan dengan pembelajaran, otak kecil bertanggung jawab dalam proses koordinasi dan keseimbangan, batang otak mengatur denyut jantung serta proses pernapasan yang sangat penting bagi kehidupan, dan simtem limbik lebih kepada pengaturan emosi dan memproses memori emosional. Secara fisik otak (neuroanatomi) terbelah menjadi dua, kiri dan kanan, tetapi perbedaan kedua belahan fisik tersebut tidak sebesar perbedaan fungsinya (neurofisiologi). Kontrol terhadap gerakan dan sensasi tubuh terbagi rata diantara dua belahan otak, hanya saja dengan cara bersilangan.

'Aql dan Otak dalam Al-Qur'an dan Neurosains :

Intelek adalah alat pemikiran yang terkandung dalam manusia, pikiran manusia berbeda dari makhluk lain karena akal hanya diberikan pada manusia dan tidak diberikan kepada makhluk lain. Perbedaan ini telah membuat manusia lebih unggul dan lebih pintar dalam mengatur hidup mereka. Karena itu manusia dengan kecerdasan yang jelas akan menemukan Tuhan sebagai hasil akhir dari kehidupan nyata. ${ }^{1}$ Salah satu unsur terpenting bagi manusia adalah akal. Akal merupakan alat untuk berpikir dan dia tidak bisa direalisasikan dalam bentuk konkritnya, akan tetapi secara abstrak akal berupa ideal yang utama dari diri manusia. Adanya akal telah mengangkat manusia lebih jauh sempurna dibandingkan dengan makhluk lain. Akal sering diidentikkan dengan otak yang selalu siap menerima segala rangsangan dari indra melalui rangsangan itulah kemudian lahir berbagai rasa dan karsa. Rekayasa tersebut terlihat adanya unsur kebenaran bila ditinjau dari segi peranannya, namun pada hakikatnya memiliki perbedaan yang jauh. Otak mempunyai kelemahan dan keterbatasan, sedangkan hakikat otak itu sendiri merupakan sarana untuk memahami dan menanggapi pengalaman, sementara akal sendiri bekerja lebih jauh lagi sesuai dengan potensi dan daya yang ada padanya. Akal mendapat pengetahuanpengetahuan yang tidak terbatas dengan pengalaman indera, ia sanggup memastikan lebih mendalam melalui pendayagunaannya. 
Nazhruna: Jurnal Pendidikan Islam

\section{Referensi}

Daming, K.M. "Akal Perspektif Al-Qur'an". Zawiyah Jurnal Pemikiran Islam 2, No.1 (2016): 19-36.

Fuadi, Lukman Hakim. "Peran Akal Menurut Pandangan Al-Ghazali". Jurnal Substantia 15, No.1 (2013): 81-90.

Hodri. "Penafsiran Akal dalam Al-Qur'an". Mutawatir: Jurnal Keilmuan Tafsir Hadis 3, No.1 (2013): 1-24.

Juwaini dan Nik Yusri bin Musa. "Konsep Akal (Suatu Analisis Terhadap Pemikiran Al-Farabi dan Ibnu Sina)". Substantia 12, No.2 (2010): 381-397.

Ma'arif, Muhammad Anas. "Pendidikan Islam dan Tantangan Modernitas (Input, Proses, Output di Madrasah)". Nidhomul Haq 1, No.2 (2016): 47-58.

Putra, Aris Try Andeas. "Pemikiran Filosofis Pendidikan Ibnu Sina dan Implikasinya Pada Pendidikan Islam Kontemporer". Literasi 6, No.7 (2015): 191-201.

Rimayati, Elfi. "Memadukan Otak dan Hati dalam Bimbingan Belajar Islam". Majalah Ilmiah Pawiyatan 20, No.2 (2013): 24-37.

Rusdianto. "Interaksi Neurosains Holistik dalam Perspektif Pendidikan dan Masyarakat Islam". Hunafa: Jurnal Studia Islamika 20, No.2 (2015): 71-94.

Samad, Sri Astuti A. "Konsep Ruh dalam Perspektif Psikologi Pendidikan Barat dan Islam". Fenomena 7, No.2 (2015): 215-216

Setiawan, Heru. "Integrasi Imtaq dan Iptek dalam Pengembangan Pendidikan Islam". Nidhomul Haq 1, No.2 (2016): 58-69.

Suyadi. "Integrasi Pendidikan Islam dan Neurosains dan Implikasinya bagi Pendidikan Dasar (PGMI)". Al-Bidayah 4, No.1 (2012): 111 130. 
Suyadi, Dosen UAD, Wawancara, UAD, 31 Mei 2018.

Suyadi. Teori Pembelajaran Anak Usia Dini dalam Kajian Neurosains. Bandung: PT Remaja Rosdakarya, 2017.

Syamsuddin, Mukhtasar. "Hubungan Wahyu dan Akal dalam Tradisi Filsafat Islam". Jurnal Filsafat. 127-148.

Wathon, Aminul. "Neurosains dalam Pendidikan". Jumal Lentera: Kajian Keagamaan, Keilmuan dan Teknologi 14, No.1 (2016): 285-294. 
Nazhruna: Jurnal Pendidikan Islam 